JPDN ISSN 2579-6461 (Online) ISSN 2460-6324 (Print)

Jurnal Pendidikan Dasar Nusantara

Volume 5 | Nomor 2 | Januari 2020|

DOI: https://doi.org/10.29407/jpdn.v5i2.13903

\title{
LEMBAR KERJA SISWA BERBASIS BUDAYA LOKAL NGADA UNTUK PEMBELAJARAN TEMATIK SISWA SEKOLAH DASAR
}

\author{
Dek Ngurah Laba Laksana ${ }^{1}$, Yosefina Uge Lawe ${ }^{2}$, Frumensia Ripo ${ }^{3}$, Maria Oliva \\ Bolo $^{4}$, Tarsisius Donbosko Dua ${ }^{5}$ \\ Email: laba.laksana@ citrabakti.ac.id ${ }^{1}$, yosefinagelawe@gmail.com², \\ ripofrumensia@gmail.com ${ }^{3}$, olivabolo@gmail.com ${ }^{4}$, tarsisiusdonbosko@gmail.com ${ }^{5}$ \\ Pendidikan Guru Sekolah Dasar, STKIP Citra Bakti ${ }^{1,2,3,4,5}$ \\ No Handphone: 081236659407
}

\begin{abstract}
Abstrak: Pembelajaran saat ini menitikberatkan pada kemampuan berpikir kritis dengan memanfaatkan sumber belajar kontekstual. Untuk itu, dilakukan penelitian dengan tujuan mendeskripsikan kualitas lembar kerja siswa berbasis budaya lokal dari aspek isi/konten, desain pembelajaran, media pembelajaran, dan pengguna produk yang sesuai dengan karakteristik anak sekolah dasar. Lembar kerja siswa terintegrasi budaya lokal dikembangkan dengan model ADDIE (analyze, design, development, implementation, dan evaluation). Data yang telah dikumpulkan dalam penelitian ini dianalisis secara deskriptif kualitatif. Dalam penelitian ini dihasilkan Lembar Kerja Siswa (LKS) tematik sekolah dasar kelas IV pada tiga tema. Persepsi ahli konten terhadap LKS berbasis budaya lokal ada pada kategori sangat baik. Persepsi ahli desain pembelajaran terhadap LKS berbasis budaya lokal ada pada kategori baik. Persepsi ahli media terhadap LKS berbasis budaya lokal ada pada kategori baik. Persepsi siswa terhadap LKS berbasis budaya lokal ada pada kategori sangat baik. Dengan demikian, LKS yang dikembangkan sudah sesuai dengan karakteristik anak sekolah dasar.
\end{abstract}

Kata kunci: Lembar kerja siswa, budaya lokal, pembelajaran tematik

\section{LOCAL NGADA CULTURE-BASED WORKSHEETS FOR THEMATIC INSTRUCTIONS OF PRIMARY SCHOOL STUDENTS}

\begin{abstract}
Recent instructions has been focusing on critical thinking skills by utilizing contextual learning resources. Therefore, this study was conducted by aiming at describing the quality of local culture-based students' worksheet from the aspect of content, instructional design, instructional media, and the product users in accordance with the characteristics of primary school students. The integrated local culture-based worksheet was developed by using ADDIE model (analyze, design, development, implementation, and evaluation). The data collected $\mathrm{n}$ study were analyzed descriptive qualitatively. Further, this study produced a thematic students' worksheet on three main topics. The perception of the expert of instructional content to the integrated localculture based worksheet was also in excellent category. On the other hand, the
\end{abstract}




\section{Dek, Yosefina, Frumensia, Maria, Tarsisius. Lembar Kerja Siswa Berbasis}

perception of the expert of instructional design and instructional media were in good category. Lastly, the perception of the students as the product users was in excellent category. Thus, it can be concluded that the developed worksheet has been suited to the primary school students' characteristics.

Keywords: Student worksheet, local culture, thematic learning

\section{PENDAHULUAN}

Dalam standar isi dalam Undang-undang Sisdiknas Nomor 20 tahun 2003 mengisyaratkan dalam proses pembelajaran, guru harus menyusun bahan ajar yang kontekstual sesuai dengan kebutuhan dan lingkungan masyarakat setempat (Depdiknas, 2003). Hal ini seiring dengan paradigma pendidikan, bahwa siswa akan mengkonstruksi pengetahuannya dari pengalaman sehari-hari mereka. Selain itu juga telah dijelaskan bahwa "manusia membutuhkan pendidikan dalam kehidupannya, pendidikan merupakan usaha agar manusia dapat mengembangkan potensi dirinya melalui proses pembelajaran dan atau cara lain, yang dikenal dan diakui oleh masyarakat". Pendidikan juga merupakan sesuatu yang fundamental dalam mencetak sumber daya manusia yang berintelektual tinggi dan mampu menjawab tantangan di masa yang akan datang.

Apalagi pembelajaran yang dilakukan di sekolah dasar, sesuai dengan teori perkembangan, bahwa anak usia 7-10 tahun (masa operasional konkret) harus belajar dari pengalaman yang bersifat nyata untuk bisa dtematikhamai dan dimengerti dengan baik oleh siswa. Penguatan dari teori belajar ini dituangkan kembali oleh pemerintah melalui Kementerian Pendidikan dan Kebudayaan melakukan uji publik sebagai pijakan lanjutan dalam mengimplementasikan kurikulum baru yaitu Kurikulum 2013. Esensi kurikulum ini pada pendidikan dasar adalah penerapan pembelajaran dengan pendekatan tematik (pembelajaran terintegrasi). Penambahan beban belajar dan pengurangan kompetensi dasar menjadi acuan bagi guru untuk menjadikan kelas aktif guna mencapai pengalaman belajar bermakna (meaningfull).

Pembelajaran bermakna akan dapat diperoleh jika anak belajar sesuai dengan lingkungan sosialnya. Sehingga unsur budaya tidak bisa dilepaskan dalam merancang sebuah pembelajaran di sekolah. Selain itu, dalam kerangka kurikulum 2013 juga disebutkan bahwa dalam menyusun dan mengembangkan kegiatan pembelajaran harus 


\section{Dek, Yosefina, Frumensia, Maria, Tarsisius. Lembar Kerja Siswa Berbasis}

memperhatikan prinsip-prinsip penyusunan dan pengembangan sesuai dengan kondisi di satuan pendidikan baik kemampuan awal peserta didik, minat, motivasi belajar, bakat, potensi, kemampuan sosial, emosi, gaya belajar, kebutuhan khusus, kecepatan belajar, latar belakang budaya, norma, nilai, dan/atau lingkungan peserta didik (Laksana, 2019).

Pembelajaran tematik merupakan pembelajaran yang sifatnya terpadu dengan penggunaan tema untuk menjaring secara keterkaitan dari berbagai bidang studi, tematema tersebut harus subur artinya tema tersebut mengundang banyak konsep dari berbagai bidang studi (tidak terpisah-pisah setiap bidang studinya). Model tematik ini dilaksanakan di kelas-kelas rendah yaitu kelas satu, kelas dua, dan kelas tiga di sekolah dasar, karena dikelas rendah pola belajar dan pola pikir anak usia SD pada umumnya masih bersumber pada segala sesuatu yang bersifat konkrit, dan dalam memakai segala sesuatu masih bersifat holistik (Dasna dkk., 2015).

Pembelajaran tematik merupakan pendekatan pembelajaran yang mengintegrasikan berbagai kompetensi dari berbagai mata pelajaran. Pengintegrasian tersebut dilakukan dalam dua hal, yaitu integrasi sikap, kemampuan/keterampilan dan pengetahuan dalam proses pembelajaran serta pengintegrasian berbagai konsep dasar yang berkaitan.

Disisi lain, dalam menerapkan pembelajaran tematik, masih banyak ditemukan permasalahan. Permasalahan kualitas hasil belajar yang belum maksimal, salah satunya dapat disebabkan karena kualitas sumber belajar. Dalam kurikulum, sebagian besar disajikan secara asbtrak (abstract material). Materi tersebut sebagian lagi semikonkret (semi-concrete material), dan hanya sebagian kecil yang merupakan materi faktual (concrete material) (Ediger \& Rao, 2003; Dick dkk., 2009). Kurikulum di sekolah sebagian besar menyajikan materi yang bersifat abstrak. Tidak terkecuali adalah materi di sekolah dasar. Pada dasarnya, sangat sulit bagi anak sekolah dasar dalam mengenal materi atau konsep dari penyajian verbalistis, sehingga diperlukan penyajian yang mampu mengkonkretkan materi yang bersifat abstrak tersebut (Ediger \& Rao, 2003; Jones \& Brown, 2011).

Peningkatan kualitas pendidikan dapat dilakukan dengan memperbaiki kualitas pembelajaran, yaitu strategi penggunaan dan pengelolaan sumber belajar (Degeng, 


\section{Dek, Yosefina, Frumensia, Maria, Tarsisius. Lembar Kerja Siswa Berbasis}

2013). Dalam belajar peserta didik selain berinteraksi dengan pendidik sebagai salah satu sumber belajar, peserta didik juga berinteraksi dengan semua sumber belajar yang mungkin dtematikkai untuk mencapai hasil yang diinginkan (Fry, Ketteridge, \& Marshall, 2014). Selain itu, dalam melaksanakan kompetensi pedagogik, pendidik dituntut memiliki kemampuan secara metodologis dalam hal perancangan dan pelaksanaan pembelajaran termasuk di dalamnya penguasaan dalam penggunaan sumber belajar (Reigeluth \& Carr-Cheliman, 2009).

Berdasarkan latar belakang tersebut di atas maka permasalahan yang dikaji dalam penelitian ini adalah bagaimanakah kualitas isi/konten, desain pembelajaran, media pembelajaran, dan pengguna produk hasil pengembangan lembar kerja siswa berbasis budaya lokal dalam pembelajaran tematik di sekolah dasar? Penelitian ini bertujuan untuk mendeskripsikan kualitas lembar kerja siswa berbasis budaya lokal dari aspek isi/konten, desain pembelajaran, media pembelajaran, dan pengguna produk agar sesuai dengan karakteristik anak sekolah dasar.

\section{METODE}

Lembar kerja siswa berbasis budaya lokal dikembangkan dengan model ADDIE. Model ini terdiri atas lima langkah, yaitu: (1) analyze, (2) design, (3) development, (4) implementation, dan (5) evaluation (McGriff, 2000). Kelima tahapan model ADDIE, dapat digambarkan seperti Gambar 1.

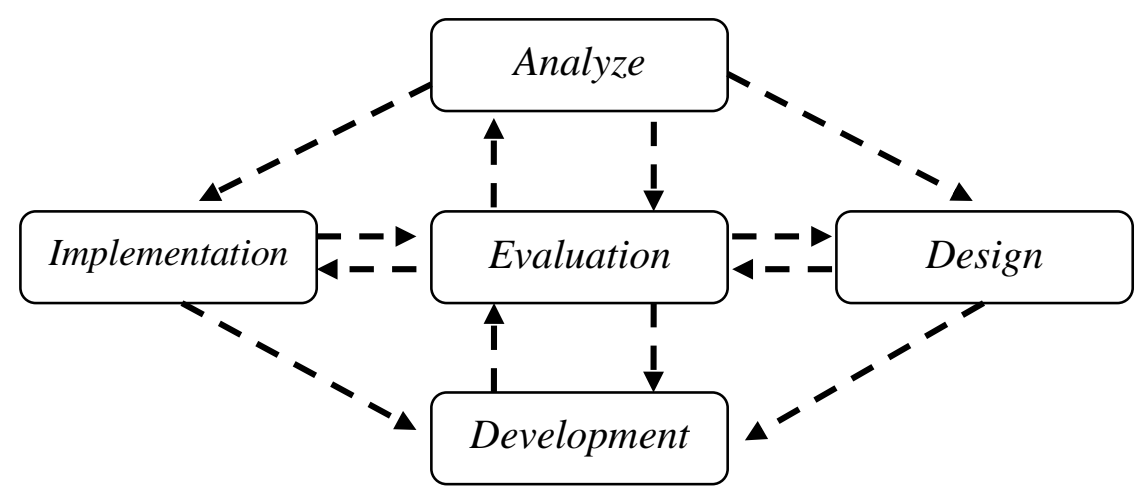

Gambar 1. Model ADDIE (McGriff, 2000)

Pada tahap analisis (analyze), meliputi kegiatan analisis kebutuhan belajar dan kompetensi inti dan kompetensi dasar materi tematik SD kelas IV. Pada tahapan 


\section{Dek, Yosefina, Frumensia, Maria, Tarsisius. Lembar Kerja Siswa Berbasis}

perancangan (design), hasil analisis kebutuhan, diintegrasikan dalam lembar kerja siswa berbasis budaya lokal untuk siswa SD kelas IV. Pada tahapan pengembangan (development), dilakukan dengan membuat lembar kerja siswa berbasis budaya lokal dengan menggunakan Microsoft Office Word dan dicetak seperti buku. Pada tahapan implementasi (implementation), kegiatan dilakukan uji coba terbatas lembar kerja siswa berbasis budaya lokal kepada guru dan siswa. Selanjutnya, pada tahapan evaluasi (evaluation), dilakukan revisi produk lembar kerja siswa berbasis budaya lokal yang dihasilkan berdasarkan hasil ujicoba.

Teknik pengumpulan data mengenai kualitas lembar kerja siswa berbasis budaya lokal dilihat dari isi, penyajian dan kebahasaan melalui review ahli dan uji coba lapangan. Review ahli dilakukan dengan menggunakan kuisioner dan dilakukan oleh ahli media serta ahli desain pembelajaran. Uji coba dilakukan melalui uji coba perorangan, uji coba kelompok kecil dan uji coba lapangan. Ujicoba lapangan menggunakan angket yang telah disusun. Data diambil setelah guru dan siswa menggunakan lembar kerja siswa berbasis budaya lokal tersebut dalam kegiatan pembelajaran.

Uji ahli melibatkan guru dan dosen serta pengujian kepada siswa sebagai pengguna produk berasal dari SDI Malanuza dan SDN Koeloda, STKIP Citra Bakti, Kabupaten Ngada, Nusa Tenggara Timur.

Data yang telah dikumpulkan dianalisis secara deskriptif kualitatif sebagai berikut. (1) Data mengenai kualitas lembar kerja siswa berbasis budaya lokal hasil review ahli dianalisis secara deskriptif untuk mengolah data hasil review ahli isi (konten) mata pelajaran, ahli desain pembelajaran, ahli media pembelajaran dan uji coba siswa.

Aspek penilaian pada ahli isi mata pelajaran mencakup kualitas materi, kualitas soal, kualitas media visual pendukung materi, dan keterkaitan materi dengan budaya lokal. Aspek penilaian pada ahli desain pembelajaran mencakup kesesuaian kompetensi inti, kompetensi dasar, indikator pembelajaran, tujuan pembelajaran, materi pembelajaran dan penilaian hasil belajar dengan materi yang tersusun pada LKS; kesesuaian organisasi materi dengan langkah-langkah pembelajaran berbasis budaya 


\section{Dek, Yosefina, Frumensia, Maria, Tarsisius. Lembar Kerja Siswa Berbasis}

lokal; serta kesesuaian materi, langkah-langkah, dan organisasi materi dengan tingkat perkembangan anak SD.

Aspek penilaian pada ahli media pembelajaran mencakup halaman depan, tipografi, tampilan, dan gambar/ilustrasi. Aspek penilaian pada ahli media pembelajaran mencakup kemenarikan tampilan LKS seperti halaman sampul, warna, gambar, tampilan huruf; dan kejelasan materi, soal-soal dan petunjuk, pengorganisasian materi.

Teknik analisis data ini dilakukan dengan mengelompokan informasi dari data kualitatif yang berupa masukan, tanggapan, kritik, dan saran perbaikan yang terdapat pada angket. Hasil analisis ini kemudian digunakan untuk merevisi produk yang dikembangkan. (2) Data mengenai kualitas lembar kerja siswa berbasis budaya lokal hasil uji coba produk dianalisis melalui konversi skor yang didapat dari lembar kuisoner.

\section{HASIL}

Dalam penelitian ini dihasilkan Lembar Kerja Siswa (LKS) tematik sekolah dasar kelas IV pada tiga tema. Tema-tema tersebut antara lain (1) LKS Tema Indahnya Kebersamaan, (2) LKS Tema Berbagai Pekerjaan, dan (3) LKS Tema Indahnya Keragaman Negeriku. Tampilan halaman depan LKS ditunjukkan pada Gambar 1. Sedangkan tampilan salah satu halaman isi dari LKS disajikan pada Gambar 2.
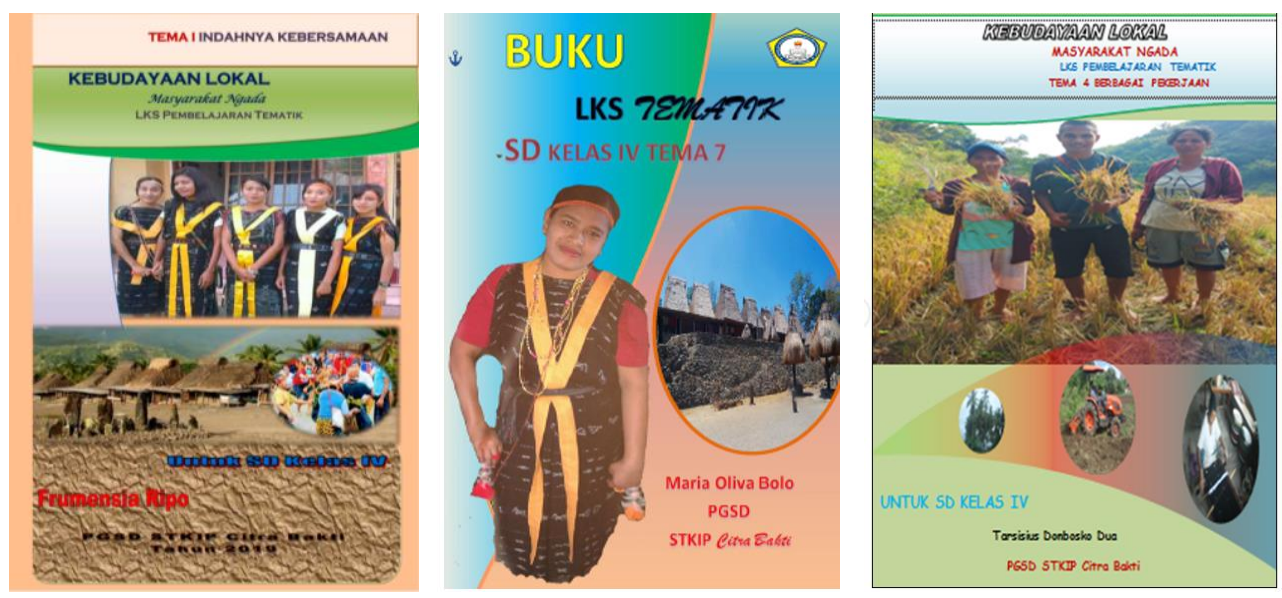

\section{Gambar 1 Tampilan depan LKS Berbasis Budaya Lokal}

LKS yang telah dikembangkan kemudian diuji coba kepada ahli konten, ahli desain pembelajaran, ahli media, dan uji coba kepada siswa SD sebagai pengguna 


\section{Dek, Yosefina, Frumensia, Maria, Tarsisius. Lembar Kerja Siswa Berbasis}

produk. Pengujian LKS oleh ahli dan pengguna produk melibatkan enam orang guru SD, tiga ahli desain pembelajaran, satu ahli media, dan 24 siswa sebagai pengguna produk.

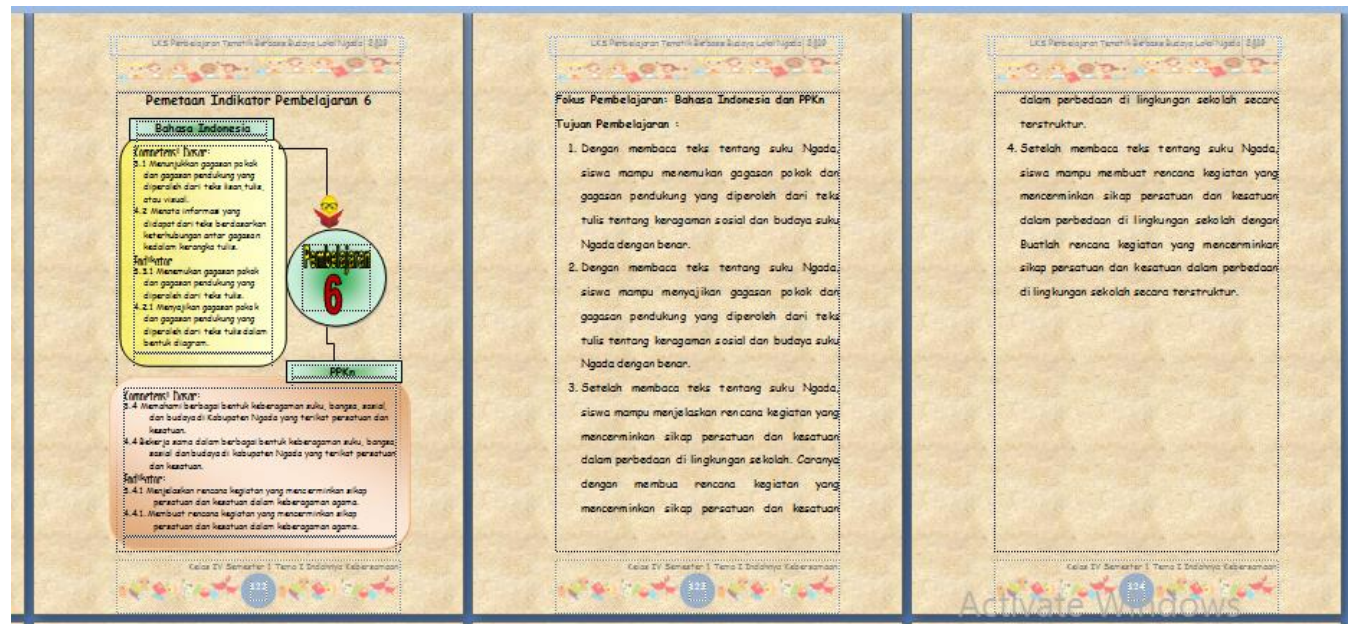

\section{Gambar 2 Salah Satu Tampilan Isi dari LKS}

Pengembangan lembar kerja siswa ini tersusun dalam enam bagian utama yaitu: (1) panduan penggunaan lembar kerja siswa, (2) jaringan tema, (3) Apa saja yang dipelajari pada tiap sub tema, (4) pemetaan indikator pembelajaran, (5) kegiatan pembelajaran, (6) soal-soal yang akan dikerjakan siswa serta petunjuk bagi siswa dalam menyelesaikan soal. Penjelasan untuk masing-masing bagian yang terdapat dalam lembar kerja siswa yang telah dikembangkan disajkan pada Tabel 1.

\section{Tabel 1 Deskripsi Bagian Utama dari LKS}

\begin{tabular}{|c|c|c|}
\hline No & Nama bagian dari LKS & Deskripsi bagian LKS \\
\hline 1 & $\begin{array}{l}\text { Panduan Penggunaan Lembar } \\
\text { Kerja Siswa }\end{array}$ & $\begin{array}{l}\text { Panduan penggunaan lembar kerja siswa ini, menjelaskan } \\
\text { kepada siswa agar siswa mendapat gambaran yang jelas } \\
\text { dan rinci mengenai proses pembelajaran berbasis konten } \\
\text { dan konteks budaya lokal masyarakat Ngada serta isi dari } \\
\text { lembar kerja siswa yang akan mereka kerjakan tersebut. } \\
\text { Selain itu juga dijelaskan cara menggunakan lembar kerja } \\
\text { siswa yang sudah dikembangkan tersebut. }\end{array}$ \\
\hline 2 & $\begin{array}{l}\text { Jaringan Tema Lembar Kerja } \\
\text { Siswa }\end{array}$ & $\begin{array}{l}\text { Jaringan tema yang terdapat pada lembar kerja siswa ini } \\
\text { berisi tentang beberapa mata pelajaran. Jaringan tema } \\
\text { dilengkapi dengan kompetensi dasar serta indikator } \\
\text { pembelajaran yang akan dicapai siswa dalam tema } \\
\text { tersebut. }\end{array}$ \\
\hline 3 & $\begin{array}{l}\text { Apa yang Akan Dipelajari } \\
\text { Siswa pada Tiap Sub Tema }\end{array}$ & $\begin{array}{l}\text { Pada setiap sub tema yang dibuat ini berisi tentang } \\
\text { kegiatan pembelajaran. Setiap kegiatan pembelajaran } \\
\text { menekankan pada kompetensi yang dikembangkan berupa } \\
\text { pengetahuan, keterampilan dan sikap pada setiap } \\
\text { pembelajaran. }\end{array}$ \\
\hline
\end{tabular}


Dek, Yosefina, Frumensia, Maria, Tarsisius. Lembar Kerja Siswa Berbasis

\begin{tabular}{cll}
\hline No & Nama bagian dari LKS & \multicolumn{1}{c}{ Deskripsi bagian LKS } \\
\hline 4 & Pemetaan Indikator & Pemetaan indikator pembelajaran, menampilkan peta \\
& Pembelajaran & indikator untuk semua materi yang menjadi fokus dalam \\
& & setiap pembelajaran. Peta indikator ini dapat \\
& & menghubungkan dan mempermudah alur pikir siswa \\
& dalam menyelesaikan soal-soal yang ada dalam lembar \\
& kerja siswa berdasarkan tema yang diajukan. \\
\hline 5 & Kegiatan Pembelajaran & Kegiatan pembelajaran terdiri dari berbagai aktivitas. \\
& Aktivitas yang dimaksud adalah aktivitas untuk melatih \\
& keterampilan dalam melakukan atau menghasilkan \\
& sesuatu. Misalnya aktivitas membaca, mengamati, \\
& berdiskusi dan menggambar. Kegiatan-kegiatan ini \\
& muncul dihampir setiap pembelajaran dan kegiatan- \\
& kegiatan ini bertujuan untuk mendorong kemampuan \\
& berpikir serta kemampuan dalam memecahkan masalah. \\
\hline 6 & Soal-soal & Soal-soal ini terintegrasi disetiap aktivitas pembelajaran. \\
& Hal ini dilakukan dengan pertimbangan, pembelajaran \\
& tematik ini menggabungkan berbagai tujuan pembelajaran \\
& dan didalamnya terdapat petunjuk-petunjuk bagi siswa \\
& dalam menjawab soal-soal yang ada pada lembar kerja \\
& siswa yang dikembangkan.
\end{tabular}

Hasil uji ahli dan pengguna produk disajikan pada Tabel 2, Tabel 3, Tabel 4, dan Tabel 5. Berdasarkan Tabel 2 mengenai persepsi ahli konten terhadap LKS berbasis budaya lokal diperoleh skor rerata sebesar 4,6 dan ada pada kategori sangat baik. Aspek yang mendapatkan skor paling tinggi adalah aspek kelengkapan materi; keakuratan konsep, prinsip, fakta, dan data; mendorong untuk mencari informasi lebih jauh; menggunakan contoh kasus yang kontekstual; dan mendukung pembelajaran berbasis budaya.

Tabel 2 Persepsi Ahli Konten terhadap LKS Berbasis Budaya Lokal

\begin{tabular}{clcc}
\hline No & \multicolumn{1}{c}{ Aspek yang dinilai } & Skor & Kategori \\
\hline 1 & Kelengkapan materi & 4,8 & Sangat baik \\
\hline 2 & Keluasan materi & 4,5 & Sangat baik \\
\hline 3 & Kedalaman materi & 4,5 & Sangat baik \\
\hline 4 & $\begin{array}{l}\text { Keakuratan konsep, prinsip, fakta, dan } \\
\text { data }\end{array}$ & 4,8 & Sangat baik \\
\hline 5 & Keakuratan contoh & 4,5 & Sangat baik \\
\hline 6 & Keakuratan soal-soal latihan & 4,3 & Sangat baik \\
\hline 7 & Keakuratan gambar, diagram, dan ilustrasi & 4,5 & Sangat baik \\
\hline 8 & Keakuratan acuan pustaka & 4,3 & Sangat baik \\
\hline 9 & $\begin{array}{l}\text { Mendorong untuk mencari informasi lebih } \\
\text { jauh }\end{array}$ & 4,8 & Sangat baik \\
\hline 10 & $\begin{array}{l}\text { Kesesuaian materi dengan perkembangan } \\
\text { ilmu dan teknologi }\end{array}$ & 4,7 & Sangat baik \\
\hline & & & \\
\hline
\end{tabular}


Dek, Yosefina, Frumensia, Maria, Tarsisius. Lembar Kerja Siswa Berbasis

\begin{tabular}{clcc}
\hline 11 & Menggunakan contoh kasus yang aktual & 4,7 & Sangat baik \\
\hline 12 & $\begin{array}{l}\text { Menggunakan contoh kasus yang } \\
\text { kontekstual }\end{array}$ & 4,8 & Sangat baik \\
\hline 13 & $\begin{array}{l}\text { Mendukung pembelajaran berbasis } \\
\text { masalah }\end{array}$ & 4,3 & Sangat baik \\
\hline 14 & Mendukung pembelajaran berbasis budaya & 4,8 & Sangat baik \\
\hline \multicolumn{2}{c}{ Rerata } & $\mathbf{4 , 6}$ & Sangat baik \\
\hline
\end{tabular}

Sementara, dari Tabel 3 mengenai persepsi ahli desain pembelajaran terhadap LKS berbasis budaya lokal diperoleh skor rerata sebesar 4,0 dan ada pada kategori baik. Semua aspek penilaian mendapatkan skor pada kategori baik. Aspek tersebut antara lain kelengkapan komponen desain pembelajaran; kelengkapan LKS; ketepatan rumusan tujuan pembelajaran; kesesuaian materi dengan tujuan pembelajaran; kesesuaian penilaian; kesesuaian materi pembelajaran, pengorganisasian materi; kenampakan pembelajaran berbasis budaya lokal; kenampakan pembelajaran berbasis masalah; dan konsistensi sistematika sajian.

Tabel 3 Persepsi Ahli Desain Pembelajaran terhadap LKS Berbasis Budaya Lokal

\begin{tabular}{clcc}
\hline No & \multicolumn{1}{c}{ Aspek yang dinilai } & Skor & Kategori \\
\hline 1 & $\begin{array}{l}\text { Kelengkapan komponen desain pembelajaran } \\
\text { (kompetensi inti, kompetensi dasar, indikator } \\
\text { pembelajaran, tujuan pembelajaran, materi pembelajaran } \\
\text { dan penilaian hasil belajar) }\end{array}$ & 4,0 & Baik \\
\hline 2 & $\begin{array}{l}\text { Kelengkapan LKS (cover, kata pengantar,daftar } \\
\text { isi,pemetaan indikator,materi pembelajaran, soal-soal } \\
\text { dan daftar pustaka) }\end{array}$ & 4,0 & Baik \\
\hline 3 & $\begin{array}{l}\text { Ketepatan rumusan tujuan pembelajaran mengacu pada } \\
\text { kata kerja operasional }\end{array}$ & 4,0 & Baik \\
\hline 4 & Kesesuaian materi dengan tujuan pembelajaran & 4,0 & Baik \\
\hline 5 & Kesesuaian penilaian dengan tujuan pembelajaran & 4,0 & Baik \\
\hline 6 & $\begin{array}{l}\text { Kesesuaian materi pembelajaran, contoh soal dengan } \\
\text { tingkat perkembangan belajar anak sekolah dasar }\end{array}$ & 4,0 & Baik \\
\hline 7 & Pengorganisasian materi dari sederhana ke kompleks & 4,0 & Baik \\
\hline 8 & Pengorganisasian materi dari konkret ke abstrak & 4,0 & Baik \\
\hline 9 & $\begin{array}{l}\text { Kenampakan pembelajaran berbasis budaya lokal dalam } \\
\text { kegiatan siswa }\end{array}$ & 4,0 & Baik \\
\hline 10 & $\begin{array}{l}\text { Kenampakan langkah-langkah pembelajaran berbasis } \\
\text { masalah dalam kegiatan siswa }\end{array}$ & 4,0 & Baik \\
\hline 11 & Konsistensi sistematika sajian dalam kegiatan belajar & 4,0 & Baik \\
\hline & $\quad$ Rerata & $\mathbf{4 , 0}$ & Baik \\
\hline
\end{tabular}


Dek, Yosefina, Frumensia, Maria, Tarsisius. Lembar Kerja Siswa Berbasis

Selanjutnya, hasil temuan berdasarkan pada Tabel 4 mengenai persepsi ahli media terhadap LKS berbasis budaya lokal diperoleh skor rerata sebesar 4,0 dan ada pada kategori baik. Aspek yang mendapatkan skor paling tinggi adalah aspek kemenarikan desain LKS.

Tabel 4 Persepsi Ahli Media terhadap LKS Berbasis Budaya Lokal

\begin{tabular}{clcc}
\hline No & \multicolumn{1}{c}{ Aspek yang dinilai } & Skor & Kategori \\
\hline 1 & Pusat pandang & 4,0 & Baik \\
\hline 2 & Komposisi dan ukuran unsur tata letak & 3,7 & Baik \\
\hline 3 & Tampilan warna & 4,0 & Baik \\
\hline 4 & Pemilihan dan penggunaan jenis huruf & 4,0 & Baik \\
\hline 5 & Ukuran huruf & 3,3 & Baik \\
\hline 6 & Pengaturan jarak & 4,0 & Baik \\
\hline 7 & Konsistensi layout/ tata letak & 4,0 & Baik \\
\hline 8 & Pemilihan background & 4,0 & Baik \\
\hline 9 & Penempatan gambar/ ilustrasi & 4,0 & Baik \\
\hline 10 & Komposisi teks dan gambar & 4,0 & Baik \\
\hline 11 & Kerapian desai LKS & 4,0 & Baik \\
\hline 12 & Kemenarikan desain LKS & 4,7 & Sangat Baik \\
\hline 13 & Dukungan terhadap materi & 4,0 & Baik \\
\hline 14 & Kemenarikan gambar/ ilustrasi & 4,0 & Baik \\
\hline & Rerata & 4,0 & Baik \\
\hline
\end{tabular}

Hasil temuan berdasarkan pada Tabel 5 mengenai persepsi siswa terhadap LKS berbasis budaya lokal diperoleh skor rerata sebesar 4,3 dan ada pada kategori sangat baik. Aspek yang mendapatkan skor paling tinggi adalah aspek kemenarikan cover; judul menarik dan mudah dibaca; dan kemenarikan gambar.

Tabel 5 Persepsi Siswa terhadap LKS Berbasis Budaya Lokal

\begin{tabular}{clcc}
\hline No & \multicolumn{1}{c}{ Aspek yang dinilai } & Skor & Kategori \\
\hline 1 & Kemenarikan cover & 4,9 & Sangat baik \\
\hline 2 & Judul menarik dan mudah dibaca & 4,5 & Sangat baik \\
\hline 3 & Pemilihan jenis huruf agar mudah dibaca & 4,2 & Sangat baik \\
\hline 4 & Ukuran huruf yang mudah dibaca & 4,2 & Sangat baik \\
\hline 5 & $\begin{array}{l}\text { Kemenarikan tampilan lembar kerja siswa cetak secara } \\
\text { keseluruhan }\end{array}$ & 4,1 & Sangat baik \\
\hline 6 & Kemenarikan warna teks, dan warna tampilan buku & 4,2 & Sangat baik \\
\hline 7 & Kejelasan ringkasan materi, soal-soal dan petunjuk & 4,2 & Sangat baik \\
\hline
\end{tabular}


Dek, Yosefina, Frumensia, Maria, Tarsisius. Lembar Kerja Siswa Berbasis

\begin{tabular}{clcc}
\hline No & \multicolumn{1}{c}{ Aspek yang dinilai } & Skor & Kategori \\
\hline & pelaksanaan tugas secara keseluruhan & & \\
\hline 8 & Kejelasan pemberian contoh & 4,3 & Sangat baik \\
\hline 9 & Kejelasan soal-soal yang dikerjakan siswa & 4,1 & Sangat baik \\
\hline 10 & Gambar mempermudah pemahaman materi & 4,2 & Sangat baik \\
\hline 11 & $\begin{array}{l}\text { Pengorganisasian aktivitas belajar yang dirancang } \\
\text { dapat mendukung pembelajaran berbasis budaya }\end{array}$ & 4,0 & Baik \\
\hline 12 & $\begin{array}{l}\text { Pengorganisasian materi ajar ditinjau dari sistematika } \\
\text { penyajian materi }\end{array}$ & 4,0 & Baik \\
\hline 13 & Kemenarikan gambar & 4,5 & Sangat baik \\
\hline 14 & Keserasian gambar terhadap soal-soal & 4,3 & Sangat baik \\
\hline Rerata & $\mathbf{4 , 3}$ & Sangat Baik \\
\hline
\end{tabular}

\section{PEMBAHASAN}

LKS berbasis budaya lokal yang dikembangkan menurut ahli konten ada pada kategori sangat baik, penilaian ahli desain pembelajaran ada pada kategori baik, penilaian ahli media pembelajaran ada pada kategori baik dan penilaian dari pengguna produk ada pada kategori sangat baik. Dari hasil penilaian tersebut, dapat diketahui bahwa LKS berbasis budaya lokal yang dikembangkan layak dan dapat digunakan dalam pembelajaran di sekolah dasar.

LKS yang dikembangkan dalam penelitian ini, sudah sesuai dengan definisi yang diberikan oleh ahli. Lembar kerja siswa adalah panduan siswa yang digunakan untuk melakukan kegiatan penyelidikan atau pemecahan masalah. lembar kerja siswa memuat sekumpulan kegiatan mendasar yang harus dilakukan oleh siswa untuk memaksimalkan pemahaman dalam upaya pembentukan kemampuan dasar sesuai indikator pencapaian hasil belajar yang harus ditempuh (Trianto, 2012).

Selain itu, menurut Prastowo (2011) menyatakan bahwa LKS memiliki keunggulan dalam penguatan aktivitas belajar. LKS dapat digunakan sebagai bahan ajar, dimana penggunaannya sebagai bahan ajar dapat meminimalkan peran guru sebagai pendidik. Dengan mengurangi dominasi pendidik, maka aktivitas siswa sebagai eserta didik lebih optimal. LKS berfungsi sebagai bahan ajar yang memudahkan peserta didik untuk memahami materi yang diberikan. LKS berfungsi sebagai bahan ajar yang ringkas dan kaya tugas untuk berlatih. LKS juga berfungsi untuk memudahkan pelaksanaan pengajaran kepada peserta didik. LKS dipakai untuk memberikan latihan 


\section{Dek, Yosefina, Frumensia, Maria, Tarsisius. Lembar Kerja Siswa Berbasis}

pengembangan. Selain itu LKS juga sebagai penunjang untuk meningkatkan aktivitas siswa dalam proses belajar dan untuk mengoptimalkan hasil belajar.

LKS bertujuan untuk menyajikan bahan ajar yang memudahkan peserta didik untuk berinteraksi dengan materi yang diberikan; menyajikan tugas-tugas yang meningkatkan penguasaan peserta didik terhadap materi yang diberikan; melatih kemandirian belajar peserta didik; penyusunan LKS juga bertujuan untuk memudahkan pendidik dalam memberikan tugas kepada peserta didik.

Penggunaan LKS dalam pembelajaran dapat memaksimalkan aktivitas belajar peserta didik dalam mengembangkan konsep, mengaktifkan peserta didik dalam proses belajar mengajar, melatih peserta didik untuk menemukan dan mengembangkan keterampilan proses. Adanya LKS dapat membantu guru dalam menyusun rencana pembelajaran, sebagai pedoman guru dan peserta didik untuk menambah informasi tentang konsep yang dipelajari melalui kegiatan belajar secara sistematis, membantu peserta didik memperoleh catatan tentang materi yang dipelajari melalui kegiatan belajar, dan membantu peserta didik untuk menambah informasi tentang konsep yang dipelajari melalui kegiatan belajar secara sistematis (Trianto, 2012).

Hasil uji coba LKS oleh ahli dan siswa sebagai pengguna produk ada pada kategori sangat baik dan baik. Persepsi peserta didik pada kemudahan dalam memahami materi dan dukungan soal-soal latihan adalah sangat baik. Hal ini berarti LKS yang dikembangkan sudah layak digunakan sebagai perangkat pembelajaran mengacu kurikulum 2013. Temuan ini juga sejalan dengan hasil pengembangan Laksana dan Wawe (2015) yang menyatakan bahwa pembelajaran IPA dengan bantuan media terutama media berbasis budaya lokal memperlihatkan hasil yang memuaskan. Aktivitas belajar meningkat yang disertai dengan penguatan pemahaman konsep IPA siswa. Selain itu, penggunaan LKS dalam pembelajaran memberikan kontribusi positif untuk keterampilan ilmiah dan pengembangan kognitif peserta didik (Awalsyah, Sarwi, Sutikno, 2018).

Temuan lain juga diungkapkan Riwu, dkk. (2018) yang menunjukan bahwa bahan ajar yang kaya media yang dikembangkan memiliki kualitas sangat baik sehingga bahan ajar layak digunakan siswa sekolah dasar dalam proses pembelajaran. Selanjutnya, Dazrullisa dan Hadi (2018; Laksana, Seso \& Riwu, 2019) mengemukakan 


\section{Dek, Yosefina, Frumensia, Maria, Tarsisius. Lembar Kerja Siswa Berbasis}

bahwa dengan menggunakan LKS berbasis kearifan lokal siswa dapat mengetahui bahwa banyak jenis kearifan lokal yang sesuai dengan materi dalam pembelajaran. Selain itu, hasil belajar siswa mengalami peningkatan saat menggunakan LKS dibandingkan dengan menggunakan buku teks. Sementara itu, Nurfitriani, Sumarmi, dan Hariyono (2018) menunjukkan bahwa buku teks yang dikembangkan telah memenuhi kriteria kevalidan, kemenarikan, kepraktisan, dan keefektifan dalam pembelajaran.

\section{SIMPULAN}

Dalam penelitian ini dihasilkan Lembar Kerja Siswa (LKS) tematik sekolah dasar kelas IV pada tiga tema. Tema-tema tersebut antara lain (1) LKS Tema Indahnya Kebersamaan, (2) LKS Tema Berbagai Pekerjaan, dan (3) LKS Tema Indahnya Keragaman Negeriku. Persepsi ahli konten terhadap LKS berbasis budaya lokal diperoleh skor rerata sebesar 4,6 dan ada pada kategori sangat baik. Persepsi ahli desain pembelajaran terhadap LKS berbasis budaya lokal diperoleh skor rerata sebesar 4,0 dan ada pada kategori baik. Persepsi ahli media terhadap LKS berbasis budaya lokal diperoleh skor rerata sebesar 4,0 dan ada pada kategori baik. Persepsi siswa terhadap LKS berbasis budaya lokal diperoleh skor rerata sebesar 4,3 dan ada pada kategori sangat baik.

\section{UCAPAN TERIMA KASIH}

Ucapan terimakasih penulis berikan kepada pihak Yayasan Pendidikan Citra Masyarakat Mandiri yang telah membantu sebagai sponsor dalam penelitian ini. Selain itu, terimakasih melimpah juga diberikan kepada SDI Malanuza dan SDN Koeloda sebagai tempat uji coba penelitian ini.

\section{DAFTAR RUJUKAN}

Awalsyah, A., Sarwi., \& Sutikno. (2018). Pengembangan lembar kerja siswa (LKS) berbasis kvisoft flipbook maker untuk mengembangkan keterampilan ilmiah siswa. Unnes Physics Education Journal, 7(3), 28-35. 
Dek, Yosefina, Frumensia, Maria, Tarsisius. Lembar Kerja Siswa Berbasis

Burkes, E.K.M. (2007). Applying cognitive load theory to desaign of online learning. Doctor of Philosophy Dissertation. Denton: University of North Texas.

Dasna, I Wayan, Laksana, D.N.L dan Sudatha I.G.W. (2015). Desain pembelajaran inovatif dan integratif. Tangerang Selatan: Universitas Terbuka.

Dazrullisa \& Hadi, K. (2018). Pengaruh lembar kerja siswa (LKS) berbasis kearifan lokal terhadap hasil belajar siswa pada materi bangun datar. BINA GOGIK, 5(2), 50-62

Depdiknas, 2003. Undang-undang Republik Indonesia Nomor 20 Tahun 2003 tentang Sistem Pendidikan Nasional.

Dick, W., Carey, L., \& Carey, J.O. (2009). The systematic design of instruction $7^{\text {th }}$ Ed. United State of America: Pearson Education.

Ediger, M. \& Rao, D.B. (2003). School curriculum and administration. New Delhi: Discovery Publishing House

Jones, T. \& Brown, C. (2011). Reading engagement: A comparison between ebooks and traditional print books in an elementary classroom. International Journal of Instruction, 4(2), 5-23

Kitao, K \& Kitao S.K. (2016). Selecting and developing teaching/learning material. The Internet TESL Journal. Diterima melalui http/:iteslj.org/Articles/Kitaomaterial.html

Laksana, D.N.L. (2019). Strategi pembelajaran: Kajian konseptual empiris di sekolah dasar. Surabaya: Krisna Bina Insan Prima

Laksana, D.N.L., \& Wawe, F. (2017). Penggunaan media berbasis budaya lokal dalam pembelajaran IPA untuk meningkatkan aktivitas belajar dan pemahaman konsep

Laksana, D.N.L., Kurniawan, P.A.W., \& Niftalia, I. (2018). Pengembangan bahan ajar tematik SD kelas IV berbasis kearifan lokal masyarakat Ngada. Jurnal Ilmiah Pendidikan Citra Bakti, 3(1), 1-10

Laksana, D.N.L., Seso, M.A., \& Riwu, I.U. (2019). Content and flores cultural context based thematic electronic learning materials: Teachers and students' perception. European Journal of Education Studies, 5(9), 145-155

McGriff, S.J. (2000). Instructional systems design: Using the ADDIE model. Pennsylvania: Penn State University 
Dek, Yosefina, Frumensia, Maria, Tarsisius. Lembar Kerja Siswa Berbasis

Nurfitriani, W., Sumarmi, \& Hariyono. (2018). Thematic text book development based on local wisdom. Jurnal Pendidikan Humaniora, 6(3), 145-151

Prastowo, A. (2011). Panduan kreatif membuat bahan ajar inovatif. Yogyakarta: Diva Press.

Reigeluth, C.M. \& Carr-Cheliman, A.A. (2009). Theories for Different Outcomes of Instruction. Dalam C.M. Reigeluth, \& A.A. Carr-Cheliman (Eds.), InstructionalDesign Theories and Models: Building a Common Knowledge Base, Vol. 3 (pp. 195-197), New York: Routledge

Riwu, I.U., Laksana, D.N.L., \& Dhiu, K.D. (2019). Pengembangan bahan ajar elektronik bermuatan multimedia pada tema peduli terhadap makhluk hidup untuk siswa sekolah dasar kelas IV di kabupaten ngada. Journal of Education Technology, 2(2), 56-64

Trianto. (2012). Pengembangan model pembelajaran tematik. Jakarta: PT. Prestasi Pustakarya 